\title{
Editorial
}

\section{De las Ciencias Sociales como Integradoras del Nuevo Conocimiento, que a su Vez Transforman Especialidad por Especialidad.}

La edición que es la tercera de la Revista FACTA NON VERBA es un homenaje a la investigación y al conocimiento interdisciplinario frente a la tradición del Derecho, la Comunicación Social y el Periodismo así como el Trabajo Social.

La mutación del conocimiento especializado se da en sincronía con una transversalidad que subyace en las denominadas ciencias sociales que en medio de los desafíos de la post modernidad, o simplemente de los tiempos corrientes, se constituyen en vanguardia de la integración, del equilibrio conceptual y edificante que a su vez se transforma.

Por ello FACTA NON VERBA se adentra en el conocimiento, la tecnología y la educación virtual así como en la investigación universitaria, y en proyectos de investigación desde las diversas áreas del conocimiento exploradas en UNIMETA.

Y si de especialidades se trata, se abordan los procesos que protegen el patrimonio de los menores, la violencia intrafamiliar, las experiencias de la comunicación alternativa en Santiago de Cali, la dignidad en el acto de morir y las diversas visiones al respecto, como también acontece con la denominada Delincuencia Organizada Transnacional.

Sea la oportunidad para invitar a los autores e investigadores para sumarse al equipo de FACTA NON VERBA que se enorgullece con la próxima publicación del libro de Derecho de Familia, de la Directora del Centro de Conciliación y Consultorio Jurídico de UNIMETA Dra Liliana Fernanda Moreno, así como el libro de cuentos del Ex Decano de la Facultad de Derecho Jorge Omar Hurtado Ruiz, y una documentada crónica de los 20 años de la Facultad a cargo de Fernando Hinestroza Daza (a cumplirse en el año 2014).

También una edición especial de FACTA NON VERBA a propósito de los 19 años de la Facultad de Derecho y el tema central "Del conflicto y su paso al Post conflicto frente a los derechos Fundamentales", en marcha durante el año 2013. engalanado con un nuevo foro esta vez sobre "Minorias étnicas y Comunidades indígenas en Colombia" para más celebraciones: los 27 años de UNIMETA, los 9 años del Centro de Conciliación Rafael Uribe Uribe, y los 15 años del Consultorio Jurídico, Guillermo Fernandez Luna.

Todo en honor de la patria en pleno proceso de paz y de las actuales generaciones, participativas e incluyentes, plenas de humanismo, como el Método Educativo MEUM, patente y orgullo de UNIMETA.

\section{The Social Sciences as Integrators of New Knowledge, Which in Turn Transform Specialty By Specialty.}

The edition is the third of the magazine FACTA NON VERBA is a tribute to the interdisciplinary research and knowledge against traditional law, the Social Communication and Journalism as well as Social Work.

The expertise mutation occurs in synchrony with a transversal underlying the so-called social sciences amid the challenges of post-modernity, or simply current times, constitute forefront of integration, conceptual and uplifting balance which in turn is transformed.

ThereforeVERBAFACTANONenters the knowledge, technologyandvirtualeducation, universityresearch, andresearchprojects from the various areas of knowledge explored in Unimeta.

And if it comes specialties, addresses the processes that protect the heritage of children, domestic violence, experience of alternative communication in Santiago de Cali, dignity in the act of dying and the different views on the matter, as well happens with the so-called Transnational Organized Crime.

Be the opportunity to invite the authors and researchers to join the team of FACTA NON VERBA that prides itself with the forthcoming publication of the book of Family Law, from the Director of the Center for Conciliation at Unimeta Legal Office, Dr Liliana Fernanda Moreno and storybook as former Dean of the Faculty of Law Jorge Omar Hurtado Ruiz and a documented chronicle of 20 years of the Law School by Fernando Hinestroza Daza (to be fulfilled in 2014).

Also a special edition of FACTA NON VERBA about the 19 years of the Faculty of Law and the theme "From Conflict and Post conflict step before the Fundamental Rights", launched in 2013. Adorned with a new forum this time on "Ethnic minorities and indigenous communities in Colombia" for more celebrations: Unimeta 27 years, 9 years of the Conciliation Center Rafael Uribe Uribe, and 15 of the Legal Office, Guillermo Fernandez Luna.

All in honor of the country in the process of peace and today's generations, participatory and inclusive, full of humanism, as MEUM Educational Method, patent and pride of UNIMETA.

Benjamin Losada Posada Facta Non Verba Director UNIMETA Law School Dean 